\title{
Kienbock disease
}

\author{
INSERM
}

\section{Source}

INSERM. (1999). Orphanet: an online rare disease and orphan drug data base. Kienbock disease. ORPHA:97332

Kienbock disease is a rare bone disorder of unknown etiology characterized clinically by osteonecrosis of the carpal lunate, eventually leading to collapse of the lunate bone impacting wrist function. 